\title{
Relative toxicity of insecticides against cotton mealybug Phenacoccus solenopsis Tinsley (Hemiptera:Pseudococcidae) and its fortuous parasitod Aenasius bambawalei Hayat (Hymenoptera: Encyrtidae)
}

\author{
V. S. Nagrare*, S. Kranthi, K.R. Kranthi, V. Chinna Babu Naik, Vrushali Deshmukh, \\ Bhausaheb Naikwadi and Ashish Dahekar
}

Central Institute for Cotton Research, P. B. No. 2, Shankar Nagar P. O., Nagpur- 440010 (Maharashtra), INDIA

*Corresponding author. E-mail: vs.nagrare@gmail.com

Received: July 29, 2015; Revised received: April 7, 2016; Accepted: June 4, 2016

\begin{abstract}
Nineteen insecticidal formulations from 10 groups of insecticides were evaluated for their relative toxicity against cotton mealybug Phenacoccus solenopsis Tinsley and its fortuous parasitoid Aenasius bambawalei Hayat. Insects were exposed to cotton leaves dipped in insecticidal solutions and their mortality was recorded at 24-h intervals. Within $24 \mathrm{~h}$ of exposure, Quinalphos, Chlorpyriphos, Thiamethoxam and Profenophos have detrimental effect on both $P$. solenospis and $A$. bambawalei recorded more than $70 \%$ mortality. Thiodicarb was extremely toxic to $P$. solenopsis and least toxic to $A$. bambawalei where as Spinosad was less toxic to $P$. solenopsis and extremely toxic to $A$. bambawalei. Profenophos, Thiamethoxam and Chlorpyriphos results into $>90 \%$ mortality of $P$. solenospsis while $100 \%$ kill of $A$. bambawalei with Spinosad, Acephate and Chlorpyriphos up to 48 hours. More than $80 \%$ mortality of $P$. solenopsis with Chlorpyriphos, Profenophos, Monocrotophos, Thiamethoxam, Spinosad and of A. bambawalei with Profenophos, Monocrotophos, Flonicamid, Buprofezin, Imidacloprid, Thiamethoxam, Chlorantraniliprole, Flonicamid and Indoxacarb recorded 72 hours after exposure. While at 96 hours, cent per cent mortality of $P$. solenopsis was recorded with Monocrotophos which was equivalent to Acephate and Spinosad. Least $\mathrm{LT}_{50}$ values were found with Thiodicarb, Quinalphos and Thiamethoxam for $P$. solenopsis and higher in case of Thiodicarb for $A$. bambawalei. Spinosad, Chlorpyriphos and Quinalphos were found to be extremely toxic to $A$. bambawalei. Among the tested insecticides Thiodicarb was found effective against $P$. solenopsis and relatively safer to $A$. bambawalei may be used judiciously to manage $P$. solenopsis that have least implications on the environment.
\end{abstract}

Keywords: Cotton, Insecticides, Mealybugs, Parasitoid

\section{INTRODUCTION}

The cotton mealybug, Phenacoccus solenopsis Tinsley (Hemiptera: Pseudococcidae) has been emerging as a serious invasive pest of cotton since 2006 in India (Hodgson et al., 2008; Nagrare et al., 2009), reducing yields up to half the potential in affected cotton fields. Prior to that the species created havoc in Pakistan (Abbas et al., 2005), causing losses to the tune of 0.2 million bales (One bale $=170 \mathrm{~kg}$ ) during 2007 (Muhammad, 2007). Since then, the species has become a pest of global importance, reported on cotton and several other economically important crops in countries Nigeria (Akintola and Ande, 2008), Thailand and Taiwan (Hodgson et al., 2008), Sri Lanka (Prishanthini and Laxmi, 2009), China (Wu and Zhang, 2009), Australia (Robinson and Tapim, 2010) and Japan (Tanaka and Uesato, 2012). The species has been recorded on 194 host plants in India (Vennila et al., 2011), including fields crops, fruit plants, vegetables, ornamentals, trees, spices, weeds, etc. The species poses a serious economic threat to cotton and other agricultural crops around the world, especially in tropical regions.
Farmers rely heavily on chemical insecticides as an easy and effective way of controlling this pest. It is well known that chemical pesticides are not only expensive but also affect the natural enemy fauna. Indiscriminate use of these chemicals leads to threats such as resurgence of insects (Kumar et al., 2011), development of resistance in insects, environmental pollution and deleterious effects on human health.

Several naturally occurring predators and parasitoids of mealybugs have been identified (Nagrare et al., 2011; Suroshe et al., 2013) among them fortuous parasitoid, Aenasius bambawalei Hayat (Hymenoptera: Encyrtidae), an endophagous, nymphal solitary parasitoid of $P$. solenopsis causes average $30 \%$ parasitization (Nagrare et al., 2011). A. bambawalei was first described and reported from India (Hayat, 2009) and is the only dominant and aggressive parasitoid responsible for the decline of the mealybug population in the north zone (Kumar et al., 2009). Its parasitization on $P$. solenopsis was reported in all three cotton-growing zones of India on several hosts including cotton and weeds. Its distribution has been recorded in Pakistan 
(Arif et al., 2011), China (Chen et al., 2010), Australia (Spargo et al., 2013) and now in Iran (Fallahzadeh et al., 2014).

World over numerous insecticides are being applied against $P$. solenopsis on agricultural important crops. Although insecticides are designed to kill pests, they are likely to be deleterious to the natural enemies of the pests. The knowledge of the relative toxicity of these insecticides to pest $P$. solenopsis and its natural enemies is insufficient. The objective of the present study was to understand the relative toxicity of some commonly used insecticides against $P$. solenopsis and its parasitoid A.bambawalei. The results would be useful to identify those insecticides that are effective against $P$. solenopsis and relatively safer to native parasitoid A.bambawalei.

\section{MATERIALS AND METHODS}

Experiments on relative toxicity of insecticides against P. solenopsis and A. bambawalei were carried out during April-November 2014 at the Insectary and Biocontrol Laboratory of Central Institute for Cotton Research, Nagpur, India using populations of $P$. solenopsis and A. bambawalei collected from location $21^{\circ} 2^{\prime}$ 18.4704"N, 79³'36.6912"E cotton (Gossypium hirsutum L, var., Suraj).

Test insects: Gravid females of $P$. solenopsis were separated from field collected populations and released on the sprouted potato for generating $F_{1}$ population. Mummies of mealybug were gently removed from field collected population with camel hair brush from the plant parts and released into plastic containers (18 $\mathrm{cm}$ dia. $\times 29 \mathrm{~cm}$ height) (average dimensions $8-10 \mathrm{~cm}$ length and 4-5 cm breadth) and secured with muslin cloth. The containers were kept at $27-32^{\circ} \mathrm{C}$ and relative humidity $(\mathrm{RH})$ of $35-60 \%$. Ten days old nymphs of $P$. solenopsis and freshly emerged A. bambawalei adults from mummified mealybugs were chosen for experiment.

Insecticides: Nineteen insecticides from 10 groups of insecticides were taken up for toxicity studies against mealybug $P$. solenopsis and its parasitoid A. bambawalei. Details of all the insecticides and doses taken are listed in Table 1. Fresh stock of each insecticide was procured from the open market while neem seed kernel extract (NSKE) was prepared in the laboratory (Anonymous 2014). Fresh test solutions of $100 \mathrm{~mL}$ each were prepared as per recommended doses on cotton by taking the requisite quantity of insecticides and diluted with distilled water.

Bioassay method: IRAC method No 8 (http://www. irac-online.org/content/uploads/Method_008_ v3 june09.pdf) was used for conducting bioassays against $P$. solenopsis and $A$. bambawalei. Fresh tender cotton leaves with petiole were collected from Bt cotton Jai 3028 grown in the net house without any insecticidal spray and free from insect infestation. Leaves were washed under running tap water to remove any insect infestation/dust. Washed leaves were placed on absorbent paper and shade-dried. Cut portions of petioles were wrapped with wet cotton and placed inside microcentrifuge tubes. The leaves thus prepared were dipped into the insecticidal solution and removed after 2 minutes of treatment and shade-dried.

$\boldsymbol{P}$. solenopsis: Insecticide treated leaves were placed in petri plates (9 $\mathrm{cm}$ diameter) and 20 Nos. of ten days old nymphs of $P$. solenopsis were released per leaf. Each treatment was replicated six times.

A. bambawalei: Insecticide treated leaves were placed in transparent $1-\mathrm{L}$ plastic jars. Sterile cotton swabs dipped in honey+water $(1: 1$ ratio) were provided as a source of food for A. bambawalei. Fifteen freshly emerged adult parasitoids were released into each plastic jar, the mouth of which was secured with muslin cloth. Each treatment was replicated thrice.

In both cases, leaves treated with distilled water were used as control. The petriplates and jars were placed at room temperature $27-32{ }^{\circ} \mathrm{C}$ and $35-60 \% \mathrm{RH}$. Mortality was recorded at $24-\mathrm{h}$ intervals by counting the dead insects and discarding them every day until $96 \mathrm{~h}$. Corrected mortality was computed using Abbott's (1925) formula and data were subjected to analysis of variance under completely randomized design using the online software Web Agri Stat Package 2.0 (ICAR Research Complex for Goa, Ila Old Goa, India). A critical difference 0.05 was used to separate mean values. Probit analysis was carried with POLO-PC LeOra Software 1987.

\section{RESULTS AND DISCUSSION}

Relative toxicity of insecticide to $\boldsymbol{P}$. solenopsis and A. bambawalei at $24 \mathrm{~h}$ interval: The results showed significant toxicity of test insecticides to $P$. solenopsis and $A$. bambawalei at 24 hour after treatment (Table 2).

At $24 \mathrm{~h}$ after treatment: More than 70 per cent mortality of $P$. solenopsis was observed with Thiodicarb and Quinalphos, Thiamethoxam, Chlorpyriphos and Profenophos and mortality of $A$. bambawalei with Quinalphos, Spinosad and Chlorpyriphos up to 24 hours after exposure. Cent per cent mortality of $P$. solenopsis was observed with Thiodicarb and Quinalphos. These were followed by Thiamethoxam, Chlorpyriphos and Profenophos and were not different from each other. Highest mortality of $A$. bambawalei was recorded with Quinalphos, Spinosad and Chlorpyriphos. Negligible mortality of $P$. solenopsis was recorded with Imidacloprid, Chlorantraniliprole, Indoxacarb and Spinosad, however they were highly toxic to A. bambawalei. Neem oil, NSKE, Neem oil+NSKE, Flubendiamide, Diafenthiuron, Novaluron, Buprofezin were found to be least toxic to either of the species. Monocrotophos and Profenophos were equally toxic to both the species.

At 48 h after treatment: Profenophos, Thiamethoxam and Chlorpyriphos results into $>90 \%$ mortality of $P$. solenospsis while $100 \%$ kill of $A$. bambawalei with Spinosad, Acephate and Chlorpyriphos. Highest mortal- 
Table 1. Details of insecticides used for toxicity study against parasitoid A. bambawalei.

\begin{tabular}{|c|c|c|c|c|c|c|}
\hline S.N. & $\begin{array}{l}\text { Group of } \\
\text { insecticidal } \\
\text { formulation } \\
\end{array}$ & $\begin{array}{l}\text { Name of } \\
\text { insecticide }\end{array}$ & $\begin{array}{l}\text { Trade } \\
\text { name }\end{array}$ & Mode of action & $\begin{array}{l}\text { Manufacturing } \\
\text { company }\end{array}$ & Dose \\
\hline 1 & Biorationals & $\begin{array}{l}\text { Neem oil } \\
(1500 \mathrm{ppm})\end{array}$ & & Antifeedent & Neem foundation & $2.5 \mathrm{l} / \mathrm{ha}$ \\
\hline 2 & & NSKE $5 \%$ & & Antifeedent & Neem foundation & $5 \%$ \\
\hline 3 & Neonicotinoid & $\begin{array}{l}\text { Imidacloprid } \\
30.5 \% \mathrm{SC}\end{array}$ & $\begin{array}{l}\text { Confi- } \\
\text { dor }\end{array}$ & $\begin{array}{l}\text { Binds irreversibly to post- } \\
\text { synaptic nicotinic acetyl- } \\
\text { choline receptors }\end{array}$ & $\begin{array}{l}\text { Bayer crop science } \\
\text { ltd. }\end{array}$ & $\begin{array}{l}20 \text { g a.i./ } \\
\text { ha }\end{array}$ \\
\hline 4 & & $\begin{array}{l}\text { Thiamethoxam } \\
25 \% \text { WG }\end{array}$ & Exaam & $\begin{array}{l}\text { Contact, stomach and } \\
\text { systemic activity }\end{array}$ & $\begin{array}{l}\text { Coromondal Agrico } \\
\text { Pvt Ltd }\end{array}$ & $\begin{array}{l}25 \text { g a.i./ } \\
\text { ha }\end{array}$ \\
\hline 5 & Carbamates & $\begin{array}{l}\text { Thiodicarb } 75 \% \\
\text { WP }\end{array}$ & Larvin & Stomach \& Contact & $\begin{array}{l}\text { Bayer crop science } \\
\text { ltd }\end{array}$ & $\begin{array}{l}1500 \mathrm{~g} \\
\text { a.i./ha }\end{array}$ \\
\hline 6 & $\begin{array}{l}\text { Anthanilic dia- } \\
\text { mides }\end{array}$ & $\begin{array}{l}\text { Chloran- } \\
\text { traniliprole } 18.5 \% \\
\text { SC }\end{array}$ & $\begin{array}{l}\text { Cor- } \\
\text { agen }\end{array}$ & $\begin{array}{l}\text { Activate insect ryanodine } \\
\text { receptors }\end{array}$ & $\begin{array}{l}\text { EI Dupont India pvt } \\
\text { Ltd }\end{array}$ & $\begin{array}{l}50 \mathrm{~g} \text { a.i./ } \\
\text { ha }\end{array}$ \\
\hline 7 & $\begin{array}{l}\text { Pyridinecarbox- } \\
\text { amide }\end{array}$ & $\begin{array}{l}\text { Flonicamid 50\% } \\
\text { WG }\end{array}$ & Ulala & $\begin{array}{l}\text { Systemic and translaminar } \\
\text { activity }\end{array}$ & $\begin{array}{l}\text { United phosphorus } \\
\text { ltd }\end{array}$ & $200 \mathrm{gm} / \mathrm{ha}$ \\
\hline 8 & $\begin{array}{l}\text { Benzenedicar- } \\
\text { boxamides }\end{array}$ & $\begin{array}{l}\text { Flubendiamide } \\
480 \% \mathrm{SC}\end{array}$ & Fame & $\begin{array}{l}\text { Stomach insecticide with a } \\
\text { new target site }-\mathrm{Ca}+\text { re- } \\
\text { lease channels }\end{array}$ & Bayer & $125 \mathrm{ml} / \mathrm{ha}$ \\
\hline 9 & Insect Growth & $\begin{array}{l}\text { Diafenthiuron } \\
50 \% \text { WP }\end{array}$ & $\begin{array}{l}\text { Pega- } \\
\text { sus }\end{array}$ & ATPase inhibitor & Syngenta & $\begin{array}{l}300 \mathrm{~g} \text { a.i./ } \\
\text { ha }\end{array}$ \\
\hline 10 & Regulators & $\begin{array}{l}\text { Novaluron } 10 \% \\
\text { EC }\end{array}$ & Rimon & IGR & Indofil & $\begin{array}{l}60 \mathrm{~g} \text { a.i./ } \\
\text { ha }\end{array}$ \\
\hline 11 & & $\begin{array}{l}\text { Buprofezin 25\% } \\
\text { SC }\end{array}$ & $\begin{array}{l}\text { Phy- } \\
\text { laud }\end{array}$ & Chitin synthesis inhibitor & $\begin{array}{l}\text { Phyto Chem (India) } \\
\text { Ltd }\end{array}$ & $\begin{array}{l}100 \mathrm{~g} \text { a.i./ } \\
\text { ha }\end{array}$ \\
\hline 12 & & $\begin{array}{l}\text { Quinolphos 25\% } \\
\text { EC }\end{array}$ & Starlux & $\begin{array}{l}\text { Translaminar stomach and } \\
\text { contact }\end{array}$ & SWAL corporation & $\begin{array}{l}500 \mathrm{~g} \text { a.i. } / \\
\text { ha }\end{array}$ \\
\hline 13 & & Acephate $75 \%$ SP & $\begin{array}{l}\text { Spit } \\
\text { fire }\end{array}$ & $\begin{array}{l}\text { Broad spectrum systemic, } \\
\text { ovicidal, contact and } \\
\text { stomach }\end{array}$ & $\begin{array}{l}\text { Chemtura chemicals } \\
\text { india pvt ltd }\end{array}$ & $\begin{array}{l}400 \mathrm{~g} \text { a.i./ } \\
\text { ha }\end{array}$ \\
\hline 14 & Organophosphate & $\begin{array}{l}\text { Chlorpyriphos } \\
20 \% \text { EC }\end{array}$ & $\begin{array}{l}\text { Durs- } \\
\text { ban }\end{array}$ & $\begin{array}{l}\text { Non-systemic, contact, } \\
\text { stomach, and vapour ac- } \\
\text { tion }\end{array}$ & $\begin{array}{l}\text { Dow Agro sciences } \\
\text { India Pvt Ltd }\end{array}$ & $\begin{array}{l}250 \text { g a.i./ } \\
\text { ha }\end{array}$ \\
\hline 15 & & $\begin{array}{l}\text { Profenophos } 50 \% \\
\text { EC }\end{array}$ & $\begin{array}{l}\mathrm{Cu}- \\
\text { racron }\end{array}$ & $\begin{array}{l}\text { Non-systemic, stomach } \\
\text { and contact }\end{array}$ & Syngnta india ltd & $\begin{array}{l}1000 \mathrm{~g} \\
\text { a.i./ ha }\end{array}$ \\
\hline 16 & & $\begin{array}{l}\text { Monocrotophos } \\
36 \% \text { SL }\end{array}$ & $\begin{array}{l}\text { Parry- } \\
\text { fos }\end{array}$ & cholinesterase inhibitor & $\begin{array}{l}\text { Coromondal interna- } \\
\text { tional Ltd }\end{array}$ & $2 \mathrm{ml} / 1$ \\
\hline 17 & Oxadiazine & $\begin{array}{l}\text { Indoxacarb } 15.8 \% \\
\text { EC }\end{array}$ & Avaunt & $\begin{array}{l}\text { Blocks sodium channel in } \\
\text { nerve axon }\end{array}$ & $\begin{array}{l}\text { EI DuPont India pvt } \\
\text { Ltd }\end{array}$ & $\begin{array}{l}75 \text { g a.i./ } \\
\text { ha }\end{array}$ \\
\hline 18 & $\begin{array}{l}\text { Macrocyclic } \\
\text { lactone } \\
\text { (spinosyns) }\end{array}$ & Spinosad 45\% SC & Tracer & Contact and stomach & $\begin{array}{l}\text { Dow Agro sciences } \\
\text { India Pvt Ltd }\end{array}$ & $\begin{array}{l}75 \mathrm{~g} \text { a.i./ } \\
\text { ha }\end{array}$ \\
\hline
\end{tabular}

ity of $P$. solenopsis was recorded with Profenophos followed by Thiamethoxam and Chlorpyriphos and these were at par with each other. These insecticides were followed by Monocrotophos but were not statistically different from later two. Remaining insecticides indicated less toxicity to $P$. solenopsis. Complete mortality of $A$. bambawalei was noted when exposed to the insecticides Spinosad, Acephate and Chlorpyriphos; these values are comparable with those recorded with Imidacloprid, Thiamethoxam, Buprofezin and Profenophos. Similar trend on least toxicity to both species was observe at $48 \mathrm{~h}$ of exposure in case of Neem oil, NSKE, Neem oil+NSKE, Flubendiamide, Diafenthiuron, Novaluron, Buprofezin.

At 72 h after treatment: Mortality with Chlorpyriphos and Profenophos was comparable with Monocrotophos which was at par with Thiamethoxam, Acephate and
Spinosad in P. solenopsis. Complete kill of A. bambawalei was recorded for insecticides Profenophos, Monocrotophos, Flonicamid, Buprofezin and were equivalent with Imidacloprid, Thiamethoxam, Chlorantraniliprole, Flonicamid and Indoxacarb. Combination of neem oil and NSKE was moderately toxic and the rate was not significantly different from that due to Flubendiamide, Chlorantraniliprole and Indoxacarb. Individual formulations Neem oil and NSKE, Neem oil +NSKE, Diafenthiuron and Novaluron proved to be the least toxic to A. bambawalei.

At 96 h after treatment: At 96 hrs of exposure, cent per cent mortality of $P$. solenopsis was recorded with Monocrotophos which was equivalent to Acephate and Spinosad. Combination of Neem formulation and NSKE were found to be moderately toxic, which was not significantly different from that due to Indoxacarb, 
Table 3. Estimated $\mathrm{LT}_{50}$ for $P$. solenopsis and $A$. bambawalei exposed to different insecticides.

\begin{tabular}{|c|c|c|c|c|c|c|c|c|c|}
\hline S. & Insecticide & $\mathbf{L T}_{50}(\mathbf{h})$ & & LFL & & UFL & & Slope \pm SEN & \\
\hline & & $\begin{array}{l}P . \\
\text { solenop- } \\
\text { sis } \\
\end{array}$ & $\begin{array}{l}\text { A. } \\
\text { bamba } \\
\text { walei }\end{array}$ & $\begin{array}{l}P . \\
\text { soleno } \\
\text { psis } \\
\end{array}$ & $\begin{array}{l}\text { A. } \\
\text { bamba } \\
\text { walei }\end{array}$ & $\begin{array}{l}P . \\
\text { soleno } \\
\text { psis } \\
\end{array}$ & $\begin{array}{l}\text { A. } \\
\text { bamba } \\
\text { walei }\end{array}$ & $\begin{array}{l}\text { P. solenop- } \\
\text { sis }\end{array}$ & $\begin{array}{l}A . \\
\text { bamba } \\
\text { walei }\end{array}$ \\
\hline 1 & $\begin{array}{l}\text { Neem oil } \\
(1500 p p m)\end{array}$ & 306.71 & 71.17 & 170.79 & 46.49 & 1851.92 & 98.17 & $\begin{array}{l}1.499 \pm \\
0.400\end{array}$ & $\begin{array}{l}3.046 \pm 0 . \\
217\end{array}$ \\
\hline 2 & NSKE 5\% & 156.18 & 84.22 & 110.40 & 57.48 & 348.10 & 116.58 & $\begin{array}{l}1.490 \pm \\
0.329\end{array}$ & $\begin{array}{l}3.878 \pm 0 . \\
260\end{array}$ \\
\hline 3 & $\begin{array}{l}\text { Neem oil+NSKE } \\
5 \%\end{array}$ & 152.68 & 69.98 & 109.82 & 48.92 & 317.65 & 70.52 & $\begin{array}{l}1.567 \pm \\
0.334\end{array}$ & $\begin{array}{l}4.777 \pm 0 . \\
300\end{array}$ \\
\hline 4 & $\begin{array}{l}\text { Imidacloprid } 30.5 \% \\
\mathrm{SC}\end{array}$ & 125.97 & 15.89 & 94.48 & 7.31 & 232.55 & 23.61 & $\begin{array}{l}1.508 \pm \\
0.319\end{array}$ & $\begin{array}{l}2.260 \pm 0 . \\
289\end{array}$ \\
\hline 5 & $\begin{array}{l}\text { Thiamethoxam 25\% } \\
\text { WG }\end{array}$ & 3.80 & 16.86 & 0.04 & 5.70 & 10.54 & 26.06 & $\begin{array}{l}1.104 \pm \\
0.362\end{array}$ & $\begin{array}{l}2.176 \pm 0 . \\
273\end{array}$ \\
\hline 6 & $\begin{array}{l}\text { Thiodicarb } 75 \% \\
\text { WP }\end{array}$ & 1.58 & 110.37 & - & 74.90 & - & 186.68 & $\begin{array}{l}1.416 \pm \\
0.680\end{array}$ & $\begin{array}{l}2.034 \pm 0 . \\
186\end{array}$ \\
\hline 7 & $\begin{array}{l}\text { Chlorantraniliprole } \\
18.5 \% \mathrm{SC}\end{array}$ & 204.05 & 13.67 & 132.44 & 0.69 & 614.64 & 26.20 & $\begin{array}{l}1.472 \pm \\
0.347\end{array}$ & $\begin{array}{l}1.791 \pm 0 . \\
262\end{array}$ \\
\hline 8 & $\begin{array}{l}\text { Flonicamid 50\% } \\
\text { WG }\end{array}$ & 87.70 & 18.88 & - & 13.00 & - & 23.90 & $\begin{array}{l}1.880 \pm \\
0.312\end{array}$ & $\begin{array}{l}2.724 \pm 0 . \\
311\end{array}$ \\
\hline 9 & $\begin{array}{l}\text { Flubendiamide } \\
480 \% \text { SC }\end{array}$ & 491.14 & 46.29 & 211.23 & 25.96 & $\begin{array}{l}18748.2 \\
5\end{array}$ & 63.54 & $\begin{array}{l}1.251 \pm \\
0.404\end{array}$ & $\begin{array}{l}3.205 \pm 0 . \\
247\end{array}$ \\
\hline 10 & $\begin{array}{l}\text { Diafenthiuron } 50 \% \\
\text { WP }\end{array}$ & 137.40 & 139.04 & 103.09 & 114.03 & 247.65 & 171.65 & $\begin{array}{l}1.674 \pm \\
0.332\end{array}$ & $\begin{array}{l}2.249 \pm 0 . \\
160\end{array}$ \\
\hline 11 & Novaluron $10 \%$ EC & 527.64 & 98.31 & 224.57 & 78.33 & $\begin{array}{l}29512.1 \\
9\end{array}$ & 121.50 & $\begin{array}{l}1.612 \pm 0.54 \\
1\end{array}$ & $\begin{array}{l}3.513 \pm 0 . \\
234\end{array}$ \\
\hline 12 & Buprofezin $25 \% \mathrm{SC}$ & 41.79 & 38.65 & 34.30 & 26.61 & 48.71 & 48.96 & $\begin{array}{l}1.940 \pm \\
0.293\end{array}$ & $\begin{array}{l}5.294 \pm 0 . \\
389\end{array}$ \\
\hline 13 & $\begin{array}{l}\text { Quinalphos 25\% } \\
\text { EC }\end{array}$ & 1.58 & 5.91 & - & 0.74 & - & 12.83 & $\begin{array}{l}1.416 \pm \\
0.680\end{array}$ & $\begin{array}{l}1.462 \pm 0 . \\
273\end{array}$ \\
\hline 14 & Acephate $75 \%$ SP & 31.15 & 19.34 & - & 11.91 & - & 25.48 & $\begin{array}{l}2.678 \pm \\
0.319\end{array}$ & $\begin{array}{l}2.701 \pm 0 . \\
304\end{array}$ \\
\hline 15 & $\begin{array}{l}\text { Chlorpyriphos } 20 \% \\
\text { EC }\end{array}$ & 15.30 & 3.47 & 10.10 & 0.053 & 19.32 & 10.22 & $\begin{array}{l}3.217 \pm \\
0.523\end{array}$ & $\begin{array}{l}1.249 \pm 0 . \\
309\end{array}$ \\
\hline 16 & $\begin{array}{l}\text { Profenophos } 50 \% \\
\text { EC }\end{array}$ & 15.49 & 22.99 & 10.41 & 5.69 & 19.36 & 34.52 & $\begin{array}{l}3.411 \pm \\
0.559\end{array}$ & $\begin{array}{l}3.042 \pm 0 . \\
314\end{array}$ \\
\hline 17 & $\begin{array}{l}\text { Monocrotophos } \\
36 \% \text { SL }\end{array}$ & 18.37 & 17.96 & - & 12.73 & - & 22.48 & $\begin{array}{l}2.966 \pm \\
0.417\end{array}$ & $\begin{array}{l}2.762 \pm 0 . \\
322\end{array}$ \\
\hline 18 & $\begin{array}{l}\text { Indoxacarb } 15.8 \% \\
\text { EC }\end{array}$ & 84.09 & 20.97 & 72.52 & 6.58 & 103.86 & 32.18 & $\begin{array}{l}2.256 \pm \\
0.326\end{array}$ & $\begin{array}{l}2.102 \pm 0 . \\
249\end{array}$ \\
\hline 19 & Spinosad $45 \%$ SC & 46.19 & 3.39 & 24.21 & 0.01 & 68.85 & 10.66 & $\begin{array}{l}2.256 \pm \\
0.311 \\
\end{array}$ & $\begin{array}{l}1.225 \pm 0 . \\
307\end{array}$ \\
\hline
\end{tabular}

LFL-Upper fiducial limit, UFL-Upper fiducial limit.

Flonicamid, Diafenthiuron and Chlorantraniliprole. Formulations of Neem oil, Flubendamide, Novaluron were found to be least toxic to P. solenopsis. Thiamethoxam, Chlorantraniliprole, Flonicamid, Indoxacarb killed all the test insects; neem oil, Neem oil+NSKE, Imidacloprid, and Flubendiamide proved equally toxic to the parasitoid. Thiodicarb was found safe to A. bambawalei.

Baseline toxicity $\mathbf{L T}_{50}$ of test insecticides to $\boldsymbol{P}$. solenopsis and $A$. bambawalei

LT $_{50} P$. solenopsis: The relative baseline toxicity of insecticides (Table 3) was determined against mealybug $P$. solenopsis, at respective doses. Least $\mathrm{LT}_{50}$ values were found with Thiodicarb, Quinalphos and Thiamethoxam. The slopes were steeper in Thiamethoxam, Thiodicarb and Quinalphos and were highly toxic than other insecticidal formulations. Moderate $\mathrm{LT}_{50}$ values were observed with Chlorpyriphos, Profenophos, Monocrotophos, Acephate, Buprofezin, Spinosad, Flonicamid and Indoxacarb. Imidacloprid, Diafenthiuron, Neem oil+NSKE，NSKE，Chlorantraniliprole, Neem oil, Flubendiamide and Novaluron required more time to kill $50 \%$ test insects. The relative grater time for mortality was calculated over Novaluron, that showed the highest $\mathrm{LT}_{50}$ value.

A. bambawalei: Baseline toxicity (Table 3 ) against $A$. bambawalei at the respective doses showed that the parasitoid was highly susceptible to Spinosad, Chlorpyriphos and Quinalphos. The slopes were steeper in Spinosad, Chlorpyriphos and Quinalphos, as a result of higher toxicity when compared with other insecticidal formulations. Chlorantraniliprole, Imidacloprid, Thia- 
methoxam, Monocrotophos, Flonicamid, Acephate, Indoxacarb, Profenophos, Buprofezin, Flubendiamide were moderately toxic. Neem oil+NSKE, Neem oil, NSKE , Novaluron, Thiodicarb and Diafenthiuron were the least toxic.

Within 24 h of exposure, our data clearly demonstrates detrimental effect of insecticides Quinalphos, Chlorpyriphos, Thiamethoxam and Profenophos on the survival of both $P$. solenospis and $A$. bambawalei. However, Thiodicarb was extremely toxic to $P$. solenopsis and least toxic to $A$. bambawalei whereas Spinosad was less toxic to $P$. solenopsis and extremely toxic to $A$. bambawalei.

After $48 \mathrm{~h}$, parasitoids exposed to the insecticides Spinosad, Chlorpyriphos, Acephate, Indoxacarb, Monocrotophos, Buprofezin, Thiamethoxam and Imidacloprid exhibited the highest mortality (80-100\%). However, maximum mortality of $P$. solenopsis was recorded with Profenophos, Thiamethoxam, Chlorpyriphos and Monocrotophos. Spinosad, Acephate, Indoxacarb, Imidacloprid were lesser toxic to P. solenopsis. Hence, these can be avoided against $P$. solenopsis. In the present investigation some of the insecticides tested were found to be toxic against the host insect $P$. solenopsis. These results were corroborating with the reported results (Kumar et al. 2012; Nagrare et al. 2011; Sahito et al. 2011; Huang et al. 2013). Spinosad was less effective against $P$. solenopsis was also reported by Sharma and Kaushik (2010), Nagrare and coworkers (2011) and Mandal and co-workers (2013), however high toxicity to A. bambawalei is reported herewith. Kumar et al. (2011) reported resurgence of $P$. solenopsis on cotton with repeated spray of Spinosad. Least toxicity of Spinosad to $P$. solenopsis and extremely toxic to $A$. bambawalei might be the reason behind resurgence of mealybug.

Studies also reported that Spinosad is highly toxic against the parasitoids Trichogramma galloi Zucchi. (Consoli et al. 2001), T. chilonis (Hussain et al., 2012) and Chrysoperla carnea (Medina et al. 2001); the ladybird beetle, Hippodamia convergens; the minute pirate bug, Orius laevigatus; the big-eyed bug, Geocoris punctipes; and the damsel bug, Nabis sp. (Thompson et al., 2000). Suma and co-workers (2009) have reported that Spinosad caused $100 \%$ mortality of the tested parasitoids Aphytis melinus DeBach and Coccophagus lycimnia Walker within $24 \mathrm{~h}$ of exposure, and Miles and co-workers (2000) and Williams et al. (2003) reported that it decreases parasitoid reproduction and longevity. Chlorpyriphos has a rapid and strong toxic effect on natural enemies (Toscano 2005; Carrillo et al. 2009). The findings of the present study are also in agreement with those of Kumar et al. (2011) in that application of organophosphates (Monocrotophos, Acephate, Profenophos) and Spinosad adversely affects the efficiency of $A$. bambawalei in cotton fields. Sahito and co-workers (2011) reported that activities of predators and parasitoids such as A. bambawalei, Brumus saturalus, Meno- chilus sexmaculatus, Scymnus coccivora, S. saturalis, Chrysoperla carnea and many species of spiders were significantly affected due to field application of Imidacloprid and Profenophos; a finding which is in agreement with that of the present study. Reports of Nalini and Manickavasagam (2011) indicated the high toxicity of Monocrotophos and Profenophos that caused 100\% mortality of both $A$. bambawalei and A. advena within 1 $\mathrm{h}$ while Imidacloprid took $3 \mathrm{~h}$ and Nimbecidine (neem formulation) $24 \mathrm{~h}$ to kill all test insects. We recorded mortality at 24-h intervals; however, comparative results indicate a similar trend. Chlorpyriphos, Profenophos and Quinalphos were also found to be highly toxic to Chrysoperla larvae (Shinde et al., 2009). Quinalphos completely inhibited the emergence of the parasitoid Trichogramma brasiliensis from egg (Varma and Singh 1987). Application of profenophos resulted in $100 \%$ morality of $C$. marginiventris in direct contact and residual studies (Ruberson et al., 1993) while thiodicarb was found to be harmless to larval parasitoids Carcella illota (Chaturvedi 2014) and C. carnea (Nasreen et al., 2005) which clearly indicating resembling results. Toscano et al. (2005) have also registered the higher toxicity of Buprofezin, Imidacloprid, Thiamethoxam and Chlorpyriphos against egg parasitoids, Gonatocerus ashmeadi and $G$. triguttatus.

In the recent past, insecticides belonging to various groups with different modes of action are being tried to control the invasive pest mealybug $P$. solenopsis infesting cotton and other crops. However, the waxy body coating of mealybugs hinders the penetration of insecticides to a greater degree and hence management approaches that reduce reliance on insecticides and promote conservation of natural enemies need to be studied (Kumar et al., 2012). Some of these insecticides demonstrate poor pest control but are found to be highly deleterious to natural enemies that control the pest population. The parasitoid_A. bambawalei, plays a significant role in the control of $P$. solenopsis in several Asian countries. Mealybugs have a skewed and clumped distribution and can be easily managed by predators and parasitoids (Afifi et al., 2010). It is well known that natural enemies of insect pests play a key role in biotic balance, minimising pest population levels below economic injury level. The advantage of biocontrol is now well recognized, particularly in the context of environmental protection as well as sustainable pest management. Conservation of natural enemies by way of avoiding application of harmful insecticides is necessary. Thiodicarb is reported to be relatively safer to several natural enemies like, Diglyphus intemedius (Girault) and Neochrysocharis punctiventris (Crawford) (Schuster, 1994), Eretmocerus tejanus (Jones et al., 1998), Orgilus Lepidus (Symington and Horne, 1998), Geocoris punctipes (Say), Nabis capsifonnis Germar, Nabis roseipennis Reuter, Podisus maculiventris (Say) (Boyd and Boethel, 1998), Chrysoperla carnea (Ayubi et al., 2013; Rasheed et al., 2014) and Carcella illota 
(Chaturvedi, 2014). Minimum use of low to moderately toxic insecticides like Thiodicarb (belonging to WHO class II) can find a place in management of cotton pests like $P$. solenopsis.

\section{Conclusion}

This study provides basic information regarding the relative toxicity of various insecticides over time for pest mealybug and its fortuous parasitoid A. bambawalei under laboratory conditions. Thiodicarb was extremely toxic to $P$. solenopsis and least toxic to $A$. bambawalei where as Spinosad was less toxic to $P$. solenopsis and extremely toxic to $A$. bambawalei. Profenophos, Thiamethoxam and Chlorpyriphos results into $>90 \%$ mortality of $P$. solenospsis while $100 \%$ kill of $A$. bambawalei with Spinosad, Acephate and Chlorpyriphos up to 48 hours. Among the tested insecticides Thiodicarb was found effective against $P$. solenopsis and relatively safer to $A$. bambawalei may be used judiciously to manage $P$. solenopsis.

\section{ACKNOWLEDGEMENTS}

We acknowledge funding by Agriculture Department, Government of Maharashtra through Crop Pest surveillance and Advisory Project (CROPSAP) 2009-14.

\section{REFERENCES}

Abbas, G., Arif, M.J. and Saeed, S. (2005). Systematic status of a new species of the genus Phenacoccus Cockerell (Pseudococcidae), a serious pest of cotton, Gossypium hirsutum L., in Pakistan. Pakistan Entomologist, 27: 8384.

Abbott's, W.S. (1925). A method for computing the effectiveness of an insecticide. Journal of Economic Entomology, 18: 265-676.

Afifi, A.I., El Arnaouty, S.A., Attia, A.R. and Abd Alla Ael, M. (2010). Biological control of citrus mealybug, Planococcus citri (Risso) using coccinellid predator, Cryptolaemus montrouzieri Muls. Pakistan Journal of Biological Sciences, 13: 216-22.

Akintola, A.J. and Ande A.T. (2008). First record of Phenacoccus solenopsis Tinsley (Hemiptera: Pseudococcidae) on Hibiscus rosa-sinensis in Nigeria. Agriculture Journal, 3: 1-3.

Anonymous, (2014). Available at http://www.indg.in/ agriculture/ crop production_techniques/ neem-seed- kernelextract-nske-preparation/ view? set_language $=$ en

Arif, M.I., Wazir, S., Rafiq, M., Ghaffar, A. and Mahmood, R. (2011). Incidence of Aenasius bambawalei Hayat on mealybug Phenacoccus solenopsis Tinsley and its hyperparasite, Promuscidea unfasciativentris Girault at Multan. Paper presented in 5th ICAC International Cotton Advisory Committee held at Lahore, Pakistan on February 23-25, 2011. Available at http://www.icac.org/ tis/ regional_networks/ asian_network/ meeting_5/ documents/ papers / PapArifMI-et_al.pdf.

Ayubi, A., Moravvej, G., Karimi, J. and Jooyandeh, A. (2013). Lethal effects of four insecticides on immature stages of Chrysoperla carnea (Stephens) (Neuroptera: Chrysopidae) in laboratory conditions. Turkish Journal of Entomology, 37 (4): 399-407
Boyd, M.L. and Boethel, D.J. (1998). Susceptibility of Predaceous Hemipteran Species to Selected Insecticides on Soybean in Louisiana. Journal of Econnomic entomology. DOI: http://dx.doi.org/ 10.1093/jee/91.2.401401409First published online: 1 April 1998

Carrillo, D., Pena, J.E. and Rogers M.E. (2009). Relative susceptibility of Haeckeliania sperata (Hymenoptera: Trichogrammatidae) to pesticides used in citrus and ornamental systems in Florida. Journal of Economic Entomology, 102: 905-912. doi: .http://dx.doi.org/ 10.1603/ 029.102 .0307

Chaturvedi, I. (2014). Observations on comparative efficacy of insecticides against Carcella illota and Bacillus thuringiensis. International Journal of Research in Biosciences, 3:1-6.

Chen, H.Y., Cao, R.X. and Xu Zai, F. (2010). First record of Aenasius bambawalei Hayat (Hymenoptera: Encyrtidae), a parasitoid of the mealybug, Phenacoccus solenopsis Tinsley (Hemiptera: Pseudococcidae) from China. Journal Environmental Entomology, 32: 280-282.

Consoli, F.L., Botelho, P.S.M. and Parra, J.R.P. (2001). Selectivity of insecticides to the egg parasitoid Trichogramma galloi Zucchi, (Hym., Trichogrammatidae). Journal of Applied Entomology, 125: 37-43.

Fallahzadeh, M., Japoshvili, G., Abdimaleki, R. and Saghaei, N. (2014). New records of Tetracneminae Hymenoptera, Chalcidoidea, Encyrtidae) from Iran. Turkish Journal of Zoology, 38 doi:10.3906/zoo-1309-28

Hayat, M. (2009). Description of a new species of Aenasius Walker (Hymenoptera: Encyrtidae), parasitoid of mealybug, Phenacoccus solenopsis Tinsley (Homoptera: Pseudococcidae). Biosystematica, 3: 21-25.

Hodgson, C., Abbas, G., Arif, M.J., Saeed, S. and Karar H. (2008). Phenacoccus solenopsis Tinsle (Sternorrhyncha: Coccoidea: Pseudococcidae), aninvasive mealybug damaging cotton in Pakistan and India, with a discussion on seasonal morphological variation. Zootaxa, 1913: 135.

Huang, J. and Zhang J. (2013). Synergistic effect of organic silicon surfactant in chemical control of the new invasive mealybug, Phenacoccus solenopsis Tinsley (Hemiptera: Pseudococcidae) in China. Asian Journal of Chemistry, 25: 2182-2184.

Hussain, D., Ali, A., Hassan, M.M., Ali, S., Saleem, M. and Nadeem S. (2012). Evaluation of toxicity of some new insecticides against egg parasitoid Trichogramma chilonis (Ishii) (Hymenoptera: Trichogrammitidae). Pakistan Journal of Zoology, 44: 1123-1127.

Jones, W.A., Ciomperlik, M.A. and Wolfenbarger, D.A. (1998). Lethal and sublethal effects of insecticides on two parasitoids attacking Bemisia argentifolii (Homoptera: Aleyrodidae) Biological Control, 11 (1): 70 -76 .

Kumar, R., Naitharwal, M., Chauhan, R., Pal, V. And Kranthi, K.R. 2012. Evaluation of ecofriendly control methods for management of mealybug, Phenacoccus solenopsis Tinsley in cotton. Journal of Entomology 9: 32-40.

Kumar, R., Swami, D., Pal, V.and Kranthi, K.R. (2011). Insecticide induced resurgence of mealybug, Phenacoccus solenopsis Tinsley in cotton. In Book (Edited by Kranthi, K. R.;Venugopalan, M. V.; Balasubramanya, R. H.; Kranthi, S.; Singh, S.; Blaise D.) World Cotton Research Conference-5, Mumbai, India, 7-11 November 2011, 198-202.

Kumar, R., Kranthi, K., Monga, D. and Jat S.L. (2009). Natural parasitization of Phenacoccus solenopsis Tinsley 
(Hemiptera: Pseudococcidae) on cotton by Aenasius bambawalei Hayat (Hymenoptera: Encyrtidae). Journal of Biological Control, 23, 457-460.

Mandal, D., Bhowmik, P., Halder, P. and Chatterjee, M.L. (2013). Determination of relative toxicity and base line data of different insecticides against cotton mealybug (Phenacoccus solenopsis Tinsley). The Journal of Plant Protection Sciences, 5: 26-31.

Medina, P., Budia, F., Tirry, L., Smagghe, G. and Vinuela E. (2001). Compatibility of Spinosad, Tebufenozide and Azadirachtin with Eggs and Pupae of the Predator Chrysoperla carnea (Stephens) Under Laboratory Conditions. Biocontrol Science and Technology, 11: 597-610.

Miles, M. and Dutton, R. (2000). Spinosad - a naturally derived insect control agent with potential for use in integrated pest management systems in greenhouses. In: Proceedings of the BCPC Conference-Pests and Diseases, November 13-16, British Crop Protection Council, Farnham, Surrey, UK. Brighton, UK p339-344.

Muhammad, A. (2007). Mealybug: cotton crop's worst catastrophe' published by the Centre for Agro-Informatics Research (CAIR), Pakistan in October 2007. Available at http://agroict.org/adss/MealyBug_Report.aspx.

Nagrare, V.S., Kranthi, S., Kumar, R., Dharajothi, B. Amutha, M., Deshmukh, A.J., Bisane, K.D. and Kranthi, K.R. (2011). Compendium of Cotton Mealybugs. Technical Bulletin, Central Institute for Cotton Research, Nagpur, P 42

Nagrare, V.S., Kranthi, S., Biradar, V.K., Zade ,N.N., Sangode, V., Kakde, G., Shukla, R.M., Shivare, D., Khadi, B.M. and Kranthi K.R. (2009). Widespread infestation of the exotic mealybug species, Phenacoccus solenopsis (Tinsley) (Hemiptera: Pseudococcidae), on cotton in India. Bulletin of Entomological Research, 99: 537-541

Nalini, T. and Manickavasagam, S. (2011). Toxicity of selected insecticides to mealybug parasitoids, Aenasius bambawalei Hayat and Aenasius advena Compere (Hymenoptera: Encyrtidae). Journal of Biological Control, 25: 14-17.

Nasreen, A., Mustafa, G. and Ashfaq, M. (2005). Mortality of Chrysoperla carnea (Stephens) (Neuroptera: Chrysopidae) after exposure to some insecticides; laboratory studies. South Pacific Studies Vol. 26, No.1.

Prishanthini, M. and Laxmi, V.M. (2009). The Phenococcus solenopsis. Department of Zoology, Eastern University, Sri Lanka. Available at http://www.dailynews.lk/ 2009/07/01/fea30.asp.

Rasheed, M., Bushra S. and Tariq, M. (2014). Use and impact of insecticides in mealybug control. International Journal of Advances in Biology, 1 (2): 1-11

Robinson, P and Tapim, F. (2010). Mealybug 'turmoil' sparks cotton crop fears. Available at http://www.abc.net.au/ news/stories/ 2010/02/05/ 2811656.htm

Ruberson, J.R., Herzog, G.A. and Lewis, W.J. (1993). Parasitism of the beet armyworm, Spodoptera axigua, in South Georgia cotton, Pp. 993- 997. In proceedings Beltwide Cotton Conferences, 10-14 January 1993, New Orleans, LA, National Cotton Council, Memphis, TN.

Sahito, H.A., Abro, G.H., Syed, T.S., Lanjar, A.G. and Khajjak, A.S. (2011). Screening of pesticides against cotton mealybug, Phenacoccus solenopsis Tinsley and its natural enemies on cotton crop. International Research Journal of Biochemistry and Bioinformatics, 1: 232-236.
Schuster, D.J. (1994). Life-stage specific toxicity of insecticides to parasitoids of Liriomyza trifolii (Burgess) (Diptera: Agromyzidae). International Journal of Pest Management, 40 (2): 191-194

Sharma, S.S. and Kaushik, H.D. (2010). Effect of Spinosad (a bioinsecticide) and other insecticides against pest complex and natural enemies on eggplant (Solanum melongena L.). Journal of Entomological Research, 34: 39-44.

Shinde, C.U., Patel, M.B. and Mehendale, S.K. (2009). Relative toxicity of different insecticides to the larvae of Chrysoperla carnea (stephens) under laboratory conditions. Pest Management in Horticultural Ecosystems, 15: 161-164

Spargo G., Khan, M. and Byers, K. (2013). A parasitoid of solenopsis mealybug found at Emerald. Australian Cottongrower $34,22-23$

Suma, P., Zappala, L., _Mazzeo, G. and_Siscaro, G. (2009). Lethal and sub-lethal effects of insecticides on natural enemies of citrus scale pests. Biocontrol 54, 651-661. DOI:10.1007/s10526-009-9215-z

Suroshe, S.S., _Gautam, R.D. and Fand, B.B. (2013). Natural enemy complex associated with the mealybug, Phenacoccus solenopsis Tinsley (Hemiptera: Pseudococcidae) infesting different host plants in India. Journal of Biological Control, 27: 204-210.

Symington, C.A. and Horne, P.A. (1998). Relative toxicity of pesticides to pest and beneficial insects in potato crops in Victoria, Australia. In Ecotoxicology: Pesticides and beneficial organisms (Eds.: Haskell PT, McEwen P). Published by Chapman and Hall, London

Tanaka, H. and Uesato, T. (2012). New records of some potential pest mealybugs (Hemiptera: Coccoidea: Pseudococcidae) in Japan. Applied Entomology and Zoology 47: 413-419

Thompson, G.D., Dutton, R.and Sparks, T.C. (2000). Spinosad - a Case Study: an Example from Natural Products Discovery Programme. Pest Management Science, 56: 696-702.

Toscano, N.C., Morse, J.G. and Henneberry, T.J. (2005). Compatibility of select insecticides with natural enemies of the glassy-winged sharpshooter and other pests. Available at http://files.piercesdisease.org/ proceedings/2005/2005 399-402.pdf

Varma, G.C. and Singh, P.P. (1987). Effect of insecticides on the emergence of Trichogramma Brasiliensis (Hymenoptera: Trichogrammatidae) from parasitized host eggs. Entomophaga 32, 443-448

Vennila, S., Prasad, Y.G., Prabhakar, M., Kumar, R., Nagrare, V., Amutha, M., Dharajyothi, B., Agarwal, M., Sreedevi, G., Venkateswarlu, B., Kranthi, K.R. and Bambawale, O.M. (2011). Spatio-temporal distribution of host plants of cotton mealybug, Phenacoccus solenopsis Tinsley in India, Technical Bulletin No. 26, National Centre for Integrated Pest Management, New Delhi P 50.

Williams, T., Valle, J. and Vinuela E. (2003). Is the naturally derived insecticide Spinosad compatible with insect natural enemies? Biocontrol Science and Technology, 13: 459-475.

Wu, S.A. and Zhang, R.Z. (2009). A new invasive pest, Phenacoccus solenopsis threatening seriously to cotton production. Chinese Bulletin of Entomology, 46: 159-162. 